\title{
File: Turkey, Europeanization and Civil Society: Introduction
}

\section{Thomas Diez , Apostolos Agnantopoulos \& Alper Kaliber}

To cite this article: Thomas Diez , Apostolos Agnantopoulos \& Alper Kaliber (2005) File: Turkey, Europeanization and Civil Society: Introduction, South European Society and Politics, 10:1, 1-15, DOI: $10.1080 / 13608740500037890$

To link to this article: https://doi.org/10.1080/13608740500037890

册Published online: 02 Dec 2009.

Submit your article to this journal $\pi$

LIII Article views: 1991

4 Citing articles: 42 View citing articles $\asymp$ 


\section{FILE: TURKEY, EUROPEANIZATION AND CIVIL SOCIETY}

\section{Introduction}

\section{Thomas Diez, Apostolos Agnantopoulos \& Alper Kaliber}

This article reviews the Europeanization literature and proposes to distinguish between four different kinds of Europeanization: policy-Europeanization, political Europeanization, societal Europeanization and discursive Europeanization. We link these different concepts to the impact of the EU on the current domestic transformations in Turkey and argue that existing scholarship has not sufficiently discussed the impact of Europeanization on civil society development, and the role of civil society organizations in furthering Europeanization. We establish the need to further analyze the triangle of Europeanization, civil society and Turkish political reform in a comparative perspective, introducing the other articles included in this SESP File.

Keywords: Turkey; Europeanization; European Union; Civil Society; Domestic Transformation

Relations between Turkey and the European Union (EU) and its predecessors have long been a core puzzle studied by those interested in the EU's foreign policy, and particularly in its policies towards its near abroad. This has sparked a prolific scholarship on Turkey-EU relations. However, many of these works focus on the ups and downs of this complex relationship, and on the analysis and assessment of existing as well as possible institutional linkages. Given Turkey's EU membership application in 1987 and its status as a membership candidate country since the Helsinki European Council in 1999, and given the drastic changes in Turkey's political constitution, above all the constitutional reform packages adopted by Parliament since 2001, it is time to start analyzing the impact of Turkey-EU relations on Turkish politics more systematically, and to extend the analysis on transformations in Turkish civil society at large: What exactly is the role of the EU in these changes? What are the new political 


\section{T. Diez et al.}

spaces opened up by Turkish membership candidacy? How do political and civil society actors in Turkey use the prospect of membership when promoting their own aims? And how are the aims and identities of these actors changing in this process?

Analyzing these issues should be of great importance to anyone studying south European society and politics, not only because Turkey is in southern Europe. The degree and pace of change in Turkey are having a major impact on the international politics of the Eastern Mediterranean. There are political, religious and cultural connections between Turkey and the Balkans. And while Turkey is in many ways a special case, studying the impact of EU membership candidacy in this case will provide useful points of comparison with other southern EU member states, both those that joined the EC in the 1980s, and those that, like Turkey (and now Croatia), have candidate status, or are seeking to achieve it. The question of the Europeanization of civil society is particularly pertinent to the comparison between Greece, Portugal, Spain and Turkey. In each of these cases, EU membership was not only supposed to bring economic benefits, but also to stabilize democracy and consolidate the process of further democratization. While most of the essays in this File do not explicitly engage in such a comparison, they do invite further comparative work by identifying and analyzing some of the core characteristics of Turkish politics, civil-military relations and NGO development, and the impact of the EU on these.

Europeanization is a crucial analytical concept for such a research agenda. As we will argue in the following section, Europeanization is far from a single unified concept. Instead, we distinguish four different meanings of the term (policy, political, discursive and societal Europeanization), although in practice, various forms of Europeanization will occur simultaneously and will be related to each other. All of them refer either to different ways in which Europe becomes a common reference point increasingly referred to in domestic debates, or to the alignment of policies, political processes or social identities within Europe.

For our purposes, there are at least two noteworthy characteristics of Europeanization as it is used in the literature. First, Europeanization strictly speaking is EU-ization. It occurs in the context of, and can be seen as sparked off by, European integration. At times, the influence of the EU is very overt, for instance in the case of policy directives and regulations decided on the EU-level of what is now commonly described as a multi-level polity. In other instances, the changes are subtler, such as the socialization effect that EU membership has on the outlook of national bureaucracies. Second, for the most part, Europeanization is a one-way street. While it is widely recognized that member states try to influence the ways in which European integration affects them, the very term implies increasing convergence, and is often taken to mean the imposition of particular

policies, political structures or social identities on member states and their societies. All of these aspects of Europeanization have to do with the construction and spread of what have come to be regarded as 'European' norms regarding particular policies, political procedures or societal self-definitions. In that sense, the EU is not only a normative power in the global international society (Manners 2002), but also within its own boundaries. 
Both of these characteristics are particularly prevalent in the analysis of transformations in the politics and society of EU membership candidate countries. As long as EU membership remains top of the preference agenda, the accession negotiation process accentuates the power of the EU over prospective members. The latter have to adopt the acquis communautaire, the extensive set of legal provisions, rules and norms that already exist amongst the member states, in order to fulfil the membership criteria. This is clearly a process of enforced EU-ization-in fact, it is well known that it is during the phase of membership negotiations that institutional and policy change is most radical, while socialization processes after the attainment of membership are a much slower, albeit potentially deeper. As Bahar Rumelili (2003, 2004a) has shown, Turkey-EU relations only started to be constructive in the sense of strengthening domestic reforms once Turkey was accepted as a candidate country and no longer held at bay.

The institutional and policy changes during accession negotiations are also by and large a one-way street, although several qualifications need to be added: first, domestic actors can use EU norms for their own purposes. Second, norms do not remain stable during the negotiation process, and in fact are often only constructed, or at least made explicit, in this context. The so-called Copenhagen Criteria for EU membership, now Article 6 of the Treaty on European Union, are the most obvious example of this. Indeed, the relationships between the $\mathrm{EU}$ and membership candidates can be understood as an exercise in the reconstruction of the $\mathrm{EU}$ as a normative power, and Turkey is a particularly good example of this (Diez 2004; Diez and Rumelili 2004).

However, the Turkish case also makes clear that Europeanization during membership candidacy is by no means restricted to formal adaptation processes. The changes in Turkey go much deeper than that. A core aspect of this deeper transformation is the way in which EU membership candidacy has altered the characteristics of civil society in Turkey, that is, those societal actors that are not political parties or state representatives, but engaged in the shaping and organization of Turkish society, and how it has transformed the spaces available for civil society actors to become actively involved in the organization of Turkish society and politics. We should also pay attention, however, to how civil society actors have used EU norms, or their understanding of such norms, to promote their own aims and ideas.

Before the contributors to this South European Society \& Politics File offer their reflections as a starting point for the analysis of these themes, let us shortly set out the different understandings of Europeanization, how they relate to Turkey, and how previous scholarship has addressed the issues raised in this File.

\section{Different Forms of Europeanization}

\section{Europeanization of Policies ('Policy-Europeanization')}

The most common understanding of Europeanization comes from research on public policy and concentrates on the impact of European integration on policy making, 


\section{T. Diez et al.}

including actors, policy problems, instruments, resources and styles (Radaelli 2000, p. 35). Neo-institutionalists have been particularly engaged in analyzing this form of Europeanization. Among them, historical and sociological institutionalists see Europeanization as a process of adjustment triggered by the existence of an incompatibility ('misfit') between the trajectory of European and domestic policies, and their underlying beliefs and normative assumptions (Morth 2003, p. 159; Risse et al., 2001, p. 6). Rational institutionalists, in contrast, argue that European policies challenge existing domestic equilibria and therefore alter the opportunity structures of domestic actors (Héritier et al., 2001). The two arguments are not incompatible. In the Turkish context, for instance, statist economic policies as part of the Kemalist tradition are challenged by the much more liberal rules of the European single market, but the latter also offer private economic actors new opportunities, which, if taken up, reinforce the process of change.

The extent of the challenge posed by the policy 'misfit', as well as the path of Europeanization, is partly dependent on the specific form that European policies in a particular policy area take, and whether or not the EU prescribes a specific policy for member states to follow, or relies on less specific directives or on the open method of coordination (Knill and Lehmkuhl 1999; Schmidt 2001; Bulmer and Radaelli 2004). Furthermore, the paths of Europeanization depend on a number of mediating factors. These include the capacity of domestic institutions to promote change (that is, veto players in the political system, scope and type of the executive leadership, influence of bureaucracy on the policy making process), the timing of the European input (that is, whether a country is already involved or not in a process of reform), and the mobilization of agents of change at the domestic level (Radaelli 2000, p. 47; Héritier and Knill 2001, p. 288; Cowles and Risse 2001, pp. 226-30; Börzel and Risse 2003, pp. 63-68).

Policy Europeanization does not only take place among EU members. Rather, the $\mathrm{EU}$ is in a particularly powerful position to impose its policies onto applicant countries. Heather Grabbe (2003, p. 312) identifies five ways through which the EU can do so. These include the provision of particular policy models, financial and technical assistance, giving advice and the 'twinning' of administrative staff, as well as more formal benchmarking and gate keeping. Turkey's latest reforms can be seen as the result of this asymmetric relationship, in which the EU is able to induce domestic change by providing a model as well as insisting on specific standards. However, as Bahar Rumelili discusses in her contribution to this File, this is not merely a one-way street in that EU membership candidacy also enables particular domestic actors to pursue their reform agenda more emphatically.

\section{Europeanization of Political Processes ('Political Europeanization')}

A second understanding of the term Europeanization concerns the impact of European integration on domestic institutional structures and political processes. The literature on such 'political Europeanization' concentrates on two themes. 
The first theme is concerned with the effects of European integration on national executives and administrative structures, deriving from the need to coordinate the relations between member states at the EU level, and to implement EU policies. As in the case of policy Europeanization, the findings of empirical studies have revealed that no uniform pattern has emerged and that national responses vary considerably according to national characteristics (Kassim 2003; Knill 2001). According to Goetz (2000, p. 217), this not only reflects the extraordinary resilience of national institutions, but also signals that European integration should best be seen as a trigger or an intervening variable in domestic institutional development rather than a major driving force. Similarly, one may argue that European integration was only one among a number of factors leading to political change in Turkey, and in particular that it acted as a reference point to frame and legitimize demands by alternative domestic actors, such as NGOs and other civil society protagonists (Rumelili 2004b).

The second research agenda of political Europeanization analyzes the influence of European integration on political actors such as political parties (Mair 2000), parliaments (Raunio and Hix 2000), interest groups (Cowles 2001), and subnational governments (Börzel 1999). In contrast to the study of policy Europeanization, such research has so far been of a primarily empirical and case-specific nature, and has produced less general theorization. The findings do however point to the fact that European integration does not necessarily reinforce national governments. Instead, it might also empower other domestic actors because it provides exit opportunities, veto points and informational advantages (Hix and Goetz 2000, p. 10). Such a differential empowerment of domestic actors is also reflected in the concepts of multilevel (Marks 1996) and network governance (Kohler-Koch 1999), which point to the emergence of a new process of governing that does not rely solely on a centralized, hierarchical form of government.

To the analysis of the Europeanization of civil society, the concept of political Europeanization is more central than policy Europeanization, although in practice, one would expect both to be interlinked. The contributions to this file on Europeanization and Turkey consequently focus in particular on the way that the membership candidacy has altered the political and societal context in which specific actors operate, and how this has altered their positions and power to influence policy making.

\section{Europeanization of Identities ('Societal Europeanization')}

A third understanding of Europeanization operates on a rather more fundamental level and can be defined as a process of change in the 'construction of systems of meanings and collective understandings' within the context of European integration (Cowles and Risse 2001, p. 219). This does not imply that national identities (in the sense of collective systems of meaning and (self-) understanding on a national level) will be replaced by a single European identity. Rather, the EU and Europe become reference points in the construction of social identities and alter the way in which such 


\section{T. Diez et al.}

identities are constructed and represented. Within this strand of the literature on Europeanization, we can again distinguish two broad research agendas.

The first sees the creation of a European identity as a reflection of EU norms, including informal ones. The main idea is that EU norms not only regulate behaviour, but also - and perhaps most importantly-influence the way actors see themselves, and therefore affect their preferences. From this perspective, Europeanization can be understood as a process of international socialization, entailing the internalization of constitutive beliefs and practices institutionalized in a state's international environment (Schimmelfennig 2000, p. 111). A great amount of research has been done on how the frequency of interactions within various EU institutions and the application of informal procedural rules of appropriate behaviour have influenced the self-perceptions of national officials and created a sense of we-feeling among them. This has encouraged coordination even in fields such as foreign policy, where the formal commitments deriving from the acquis communautaire are relatively few (Glarbo 2001; Smith 2000; Jorgensen 1997). In the same vein, the substantive dimension of the EU normative basis (Manners 2002) which is comprised in the acquis and the Copenhagen criteria and includes a commitment to peace, liberty, democracy, the rule of law and human rights, serves as an important focal point around which national identities are fashioned (Cowles and Risse 2001, p. 221). This research agenda has a lot in common with the sociological institutionalist literature on policy Europeanization, but here the focus is broader and includes not only change in policy beliefs but also how societal self-definitions evolve through the process of Europeanization.

The second research agenda concentrates on the intersubjective meaning that people attach to the EU as a whole and the repercussions that this meaning has on national identities. The basic idea is that there are different constructions of the EU and Europe. The more these identity constructions resonate with the ideas about the nation and political order embedded in national identities, the more likely they are to be incorporated in these identities (Risse 2001, p. 202; Wæver 1998, 2004).

Both the research on the dissemination of norms and the changing conceptions of collective identity and political order have so far largely focused on political and media elites. There are of course Eurobarometer studies on a mass survey level on whether people 'feel' European (for example, European Commission 2001, pp. 10-11), but these suffer from the methodological problem of how to observe and measure societal Europeanization. Conceptualizing collective identity on such a level is notoriously difficult, and likely itself to engage in identity construction rather than measurement. Nonetheless, societal Europeanization is an important aspect of any study of how EU membership candidacy has affected Turkish civil society.

\section{Europeanization of Public Discourses ('Discursive Europeanization')}

A final concept of Europeanization will be less familiar to most readers. It is also less relevant to the study of Europeanization and Turkish civil society, but it should 
nonetheless at least be mentioned here, as it provides a useful additional angle to study Europeanization in the Turkish case and does indeed play a role in Metin Heper's analysis of military-civil relations. Studies of the Europeanization of public discourses (or 'discursive Europeanization') have analyzed to what extent public claims make reference to the EU, specific European actors or policies, and how this has changed over time (see http://europub.wz-berlin.de). The underlying idea is that in a (fictive) perfect nationally organized discourse, political actors would operate solely within a national context, and references to actors outside this context would be rare. On the opposite end, an (equally fictive) perfectly Europeanized public discourse would see all political actors routinely make reference to the European level. Such an analysis gets around some of the methodological problems of the study of societal Europeanization, but as a formal analysis of references, it lacks an understanding of the substantive nature of change, which is our interest in the present context.

\section{Europeanization and Turkish Civil Society}

Even though studies of Europeanization have been an 'academic growth industry' since the mid-1990s (Olsen 2002, p. 921), scholarship on Turkish-EU relations within this framework has been the exception. Turkey's relations with the EU have been reinvigorated in the aftermath of the Helsinki Summit of 11-12 December 1999. Moreover, as Meltem Müftüler Baç argues in her contribution to this File, the adoption of successive reform packages by the Turkish National Assembly to meet the Copenhagen criteria has placed the EU at the forefront of the democratization agenda in Turkey. This has resulted in an increasing number of studies addressing Turkey's integration into the EU in terms of the development of civil society and citizenship rights in Turkey (Öniş 2002; Rumford 2001; Kubicek 2002; Hale 2003). However, these studies by and large focus on the institutional level and do not make use of the conceptual tools provided by the Europeanization literature as outlined above.

This lack of interest can partly be attributed to the Europeanization literature itself, which has so far focused largely on EU member states. Another reason is related to the fact that the agenda of Turkish-EU relations is still predominantly occupied with Turkey's macro-political deficiencies in meeting the Copenhagen criteria. Since the accession negotiations have only recently been initiated, problems arising, for instance, from misfit and divergence between Turkey and the Union in specific policy areas and institutions have not come to occupy a pivotal position in the relevant scholarship. However, the effectiveness of conditionality attached to the membership candidacy is already noted (see Schimmelfennig et al. 2003, pp. 508-9). The bulk of the existing studies on Turkey-EU relations treats Europeanization primarily as a political process and analyzes its domestic impact on Turkish politics in terms of Turkey's macro-political transformation. It therefore focuses on political Europeanization, but without providing a consistent treatment of this concept-the domestic impact of Turkey's integration into the EU is discussed either without making reference to the literature on Europeanization (Sofos 2001; Uğur 2001), 
$8 \quad$ T. Diez et al.

or without even making reference to the concept itself (Öniş 2002; Hale 2003; Rumford 2002a, 2002b).

In an article on European integration and the transformation of Turkish politics, Spyros Sofos (2001, p. 243), for instance, discusses the domestic impact of Turkey's 'volatile relationship with the EC/EU' on the transformation of the macrosociopolitical structure in Turkey, and therefore focuses on political Europeanization. After briefly recapitulating the Kemalist project of modernization 'from above', he focuses on post-1983 Turkish politics and the crises originating from the democratization of this authoritarian conception of modernity. Sofos makes the case that Turkey has been undergoing 'economic and political transformations that were set in motion in the Özal period' (Sofos 2001, p. 257), during which the EC/EU and its relations with Turkey have increasingly been integral to domestic political processes and discourses in Turkey. This transitional period is characterized by the struggle between reformist elites 'rallying around the banner of Europeanization', and the elites who are 'supporters of a statist view of Turkey under the tutelage of a suspicious and possessive military elite' (Sofos 2001, p. 256). For the reformist faction of economic and political actors, Europeanization has turned out to be 'synonymous to "democratization" or pressure to enhance and deepen liberal democracy' (Sofos 2001, p. 248). The establishment of a direct relationship between the need for liberalization and the fate of Turkey's integration into the EU has rendered 'the EU and its policies vis-à-vis Turkey' 'a permanent feature of the public discourse in Turkey' (Sofos 2001, p. 254). Furthermore, a strengthened civil society, showing 'signs of activation of social spaces' toward democratization of the domestic polity in Turkey, has legitimized its existence through 'the discourse of Europeanization', a theme taken up by Rumelili as well as Nigar Göksel and Rana Birden Güneş in their respective contributions to this File. Departing from these assumptions, Sofos reaches the conclusion that all reforms intended for the liberalization and democratization of the Turkish political system 'have been either prompted by or justified on the grounds of the EU-Turkey relationship' (Sofos 2001, p. 254).

Mehmet Uğur shares the notion that the legal and constitutional amendments introduced by successive Turkish governments during the 1990s 'were clearly related to pressures from the EU' (Uğur 2001, p. 233). However, Uğur diverges from Sofos by asserting that throughout the decade, Turkish political elites 'have consistently tried to de-link any partial reform from Turkey's European orientation' (Uğur 2001, p. 218). In formulating and legitimizing the reform agenda, integration into the EU was never accepted 'as a reference point' (Uğur 2001, p. 218). Although Uğur makes no reference to the Europeanization literature, the concept is implicitly employed in the sense of 'convergence' and harmonization with EU policy standards, norms and values. Examining Turkey's macro- and micro-economic policies, democratization and human rights practices along with its Cyprus policy, the author cites two reasons for Turkey's suboptimal and unsystematic 'convergence towards EU standards' (Uğur 2001, p. 217). The first is the incomplete nature of 'contracts governing EU-Turkey relations' (Uğur 2001, pp. 218, 237), owing to the refusal of the EU until the 1999 
Helsinki Council to play a committed 'anchor' for Turkey's transformation and set clearly identifiable criteria and targets for Turkey (Ugur 1999, pp. 242-3). The second concerns the mode of governance in Turkey, in which the 'state's dominant position vis-à-vis the society' (Uğur 2001, p. 217) has been the norm, in the historical institutionalist sense of a legacy that acts as an intermediate variable to Europeanization processes.

Uğur, Sofos and others explain the deterioration of Turkey's relations with the EU in the 1990s to a large extent in terms of Turkey's human rights record and its 'problematic democratization' (Tsakonas 2001). However, Turkey's democratic transformation and its integration into the EU are 'two mutually constituted processes' (Piccoli 2003, p. 4). In other words, a deeper penetration of the European dimension into Turkish domestic politics and society (in the sense of political and societal Europeanization) exerts an influence on Turkey's democratization process as well, as Ugur's metaphor of the 'anchor' implies. Ziya Öniş argues in this respect that the prospect of membership in the Union functions as a 'powerful engine of democratization and economic transformation in candidate countries' (Öniş 2002, p. 2) through the appropriate mix of conditionalities and incentives. However, if the EU's emphasis is on conditionalities or negative incentives only, 'this will tend to slow down' and even damage the transformation of domestic polities by strengthening the hands of Eurosceptics. As to the Turkish case, 'the institutionalized dialogue initiated by the Helsinki process' (Öniş 2002, p. 10; see also Rumelili 2004a, 2004b) and the subsequent harmonization reforms profoundly impinged on Turkish domestic politics. The postHelsinki era witnessed the emergence of a 'pro-EU coalition committed to undertaking the kinds of economic and political reforms necessary to facilitate full membership' (Öniş 2002, p. 23). However, the simultaneous flourishing of a 'highly entrenched anti-EU coalition' (Öniş 2002, pp. 18, 23) appears as a formidable obstacle before Turkey's democratic transformation and hence creates an ambivalent attitude toward the EU. To Öniş (2002, p. 18), this stalemate may be resolved through the decisive role of the EU as in the case of Central and Eastern European countries. Similarly, Chris Rumford defends the notion that heightening of expectations for democratic reforms due to EU pressure encourages 'numerous groups to enter the political arena and engage in the struggles of recognition' (Rumford 2002, p. 246).

It is true that certain civil society organizations have increasingly become vocal 'for EU-related democratic reforms' (Öniş 2002, p. 13). However, pressures from and support by civil society for EU-related reforms have remained extensively confined either to the organizations related to 'big business' and the private sector, in particular the Turkish Industrialists' and Businessmen's Association (TUSIAD) and the Economic Development Foundation (IKV), or to organizations run by liberal intellectuals, such as the Turkish Economic and Social Studies Foundation (TESEV). Furthermore, as Öniş admits, 'not all business associations are equally enthusiastic about' the EU-induced reform process (Öniş, 2002, fn. 21). Examples include the Union of the Chambers of Commerce, Industry, Maritime Trade and Stock Exchanges of Turkey (TOBB) and the Confederation of the Employers' Unions of Turkey (TISK), 


\section{T. Diez et al.}

even if they do not adopt such a strict line as labour unions such as the Confederation of Labour Unions of Turkey (TÜRK-İŞ). ${ }^{1}$ In this File, too, we have included a contribution written from the perspective of activists in a liberal NGO (Göksel and Güneş from the ARI movement). Further research will have to be done on the impact that the EU membership candidacy has had, for example, on religious groups.

The main factor restricting the power of Turkish civil society as an autonomous 'realm of possibility for political change' (Rumford 2002, p. 273) lies in its extremely heterogeneous and even fragmented structure (Kubicek 2001, p. 38). For instance, it is unrealistic to expect 'pro-Kemalist' civil society organizations 'enforcing the restoration of the existing legal-institutional framework along the lines of laicism, modern life, national unity, and nationalism' (Erdoğan 2000, p. 252) to vigorously support all democratization reform. This is especially the case if such reforms are deemed incompatible with Kemalist principles - the misfit would be too great to make such a support likely. As Kubicek (2002, p. 770) argues, the level of politicization in civil society is still relatively low, and the separation 'between formal politics, dominated by parties, and civic groups remains'.

\section{Europeanization, Turkey and Civil Society: An Overview}

Given the existing literature on Europeanization, and the effect of the EU candidacy on Turkish civil society, there is a need to further explore how much the current constitutional and political change in Turkey is indeed driven by civil society actors, how it has changed the opportunities, but also the identities, aims and strategies of these actors, and whether these changes can be seen as part of a process of political and societal Europeanization. Such a research agenda will have to look not only at the transformation of particular policies in the context of the accession process and what we have labelled policy Europeanization, but also at a deeper level of change, and how policy Europeanization is related to such change. It will have to analyze how Europeanization empowers some actors and restricts the powers of others, and how these actors react to and make use of the EU context to advance their claims. The pieces collated in this File naturally do not answer all of these questions. Instead, they offer some initial reflections on particular aspects of such a research agenda.

In line with other authors (for example, Rumelili, 2003), Meltem Müftüler Baç, in her overview of political Europeanization in Turkey, notices a great push of the Europeanization process through the granting of EU membership candidacy in 1999. She reviews the constitutional reform packages adopted by Parliament since then, but identifies the rights of women as one of the major gaps between Turkish and European legal norms yet to be addressed. Both she and Metin Heper, in his contribution on Europeanization, the military and civil society, make us aware of the fact that while EU-ization is the strongest form of more recent forms of Europeanization, the idea of Europeanization in Turkey as such goes much further back in history, and is tied to modernization reforms already carried out towards the end of the Ottoman Empire (see also Jung with Piccoli 2001, pp. 28-47). 
In his piece, Heper argues that this historical societal Europeanization facilitates political and policy Europeanization today, despite resistance from within the military. His contribution makes clear that different understandings of Europeanization have prevailed at different historical junctures, and that the military has sometimes been the object, and sometimes the driving force of Europeanization processes. Heper ties the more recent Europeanization to a change from the consolidation to the deepening of democracy in Turkey, and a corresponding change from a focus on what, following Sartori, he calls 'rationalist' to 'liberal' democracy.

Bahar Rumelili then focuses on what EU membership candidacy has meant for Greek-Turkish relations at the level of civil society. She investigates the financial impact of EU funding, but also identifies shortcomings of the assistance that the EU provides. According to Rumelili, the EU's main contribution to Greek-Turkish relations is not so much in terms of funding, but lies in the platform that it has given to those who have been seeking friendly relations between the two people, and who now find it easier to legitimize their policies. Rumelili argues that this involves political and societal Europeanization, rather than merely policy Europeanization, and that the EU framework will provide a degree of stability for Greek-Turkish relations that they would otherwise not have.

The contribution by Diba Nigar Göksel and Rana Birden Güneş introduces the view of two NGO activists who have experienced the EU's impact first-hand. Both are members of the ARI movement, but have also had dealings with other NGOs. They agree with Müftüler-Bac that the political Europeanization process in Turkey really got underway after the Helsinki decision. Apart from the direct financial, legal and training benefits that NGOs have received directly or indirectly from the EU, the authors also point out the 'enabling impact' that the membership prospect has had in terms of increased prestige of NGOs and the ability to raise issues that could not have been raised easily before. Of course, the experience of the ARI movement is coloured by being broadly in favour of Turkish EU membership; but nonetheless, these reflections of two 'practitioners' provide useful information about the mechanisms of Europeanization.

Last but not least, Nathalie Tocci's comment on the preceding papers focuses on the role that the EU played in the recent changes in Turkey. She concludes that political Europeanization, which is empowering civil society actors, would itself not have come about without the pressures from those actors. Tocci concludes that the process of change is largely domestically driven, but that the EU is an important 'anchor' for this process, as the enabling impact suggested by Göksel and Güneş also suggests-at least, and here she, too, agrees with Müftüler Baç, since the decision to accept Turkey as a membership candidate.

These contributions highlight the multiple faces of Europeanization, but they also make clear that different forms of Europeanization do not occur independently from each other. In fact, the political Europeanization that seems prevalent in Turkey is at the same time embedded in and furthering societal Europeanization, as Heper notes, and policy Europeanization, as Tocci points out. The role of civil society is crucial in 


\section{T. Diez et al.}

this transformation, and again both as a driving force and as the addressee of Europeanization, as becomes clear in the contributions by Rumelili as well as Göksel and Güneş. The stress in these pieces on the domestic actors who drive Europeanization is an antidote to the often rather passive accounts in both public and academic discourse on Europeanization. It shows that, at least in the case of Turkey, this process is at least to a great part driven by these actors, who instrumentalize the $\mathrm{EU}$ as much as the $\mathrm{EU}$ enables them to articulate particular political positions.

\section{Acknowledgements}

This article was first outlined at the workshop on Europeanization and Turkey sponsored by the European Politics Research Group, Department of Political Science and International Studies, University of Birmingham. The article has also benefited from comments by the two reviewers of this journal, as well as the work of the project 'The European Union and Border Conflicts' (EUBorderConf) funded by the European Commission, SERD-2002-00144, see www.euborderconf.bham.ac.uk.

\section{Notes}

[1] For an elaborate analysis of the attitudes and discourses of these professional chambers and associations vis-á-vis the European Union within a historical perspective see Bora (2000, pp. 99-142).

\section{References}

Börzel, T. A. (1999) 'Towards convergence in Europe? Institutional adaptation to Europeanisation in Germany and Spain', Journal of Common Market Studies, vol. 37, no. 4, pp. $573-596$.

Börzel, T. A. \& Risse, T. (2003) 'Conceptualizing the domestic impact of Europe', in The Politics of Europeanization, eds K. Featherstone \& C. M. Radaelli, Oxford University Press, Oxford, pp. $57-80$.

Bora, T. (2000) 'Professional chambers and non-voluntary organizations: the intersection of public, civil and national', in Civil Society in the Grip of Nationalism, eds S. Yerasimos, G. Seufert \& K. Vorhoff, Orient-Institut, Istanbul.

Bulmer, S. \& Radaelli, C. M., 'The Europeanization of national policy?', Queen's Papers on Europeanisation, no. 1/2004, http://www.qub.ac.uk/schools/SchoolofPoliticsInternational Studies/FileStore/EuropeanisationFiles/Filetoupload,5182,en.pdf.

Cowles, M. G. (2001) 'Whither the Service Sectors? Globalization, Europeanization, and National Patterns of Capitalism', paper presented at the seventh conference of the European Community Studies Association, Madison, Wisconsin.

Cowles, M. G. \& Risse, T. (2001) 'Transforming Europe: conclusions', in Transforming Europe: Europeanization and Domestic Change, eds M. G. Cowles, J. A. Caporaso \& T. Risse, Cornell University Press, Ithaca, NY, pp. 217-261. 
Diez, T. (2004) 'Europe's others and the return of geopolitics', Cambridge Review of International Affairs, vol. 17, no. 2, pp. 319-335.

Diez, T. \& Rumelili, B. (2004) 'Open the door!', The World Today, vol. 2004, Aug./Sept. 2004, pp. $18-19$.

Erdoğan, N. (2000) 'Kemalist non-governmental organizations: troubled elites in defence of a sacred heritage', in Civil Society in the Grip of Nationalism, eds S. Yerasimos, G. Seufert \& K. Vorhoff, Orient-Institut, Istanbul, pp. 251-282.

European Commission. (2001) How Europeans See Themselves: Looking through the Mirror with Public Opinion Surveys, Office for Official Publications of the European Communities, Luxembourg.

Glarbo, K. (2001) 'Reconstructing a common European foreign policy', in The Social Construction of Europe, eds T. Christiansen, K. E. Jørgensen \& A. Wiener, Sage, London, pp. 140-157.

Goetz, K. H. (2000) 'European integration and national executives: a cause in search of an effect?', West European Politics, vol. 23, no. 4, pp. 211-231.

Grabbe, H. (2003) 'Europeanization goes East: power and uncertainty in the EU accession process', in The Politics of Europeanization, eds K. Featherstone \& C. M. Radaelli, Oxford University Press, Oxford, pp. 303-330.

Hale, W. (2003) 'Human rights the European Union and the Turkish accession process', in Turkey and the European Union: Domestic Politics, Economic Integration and International Dynamics, eds A. Çarkoğlu \& B. Rubin, Frank Cass, London, pp. 107-126.

Héritier, A., Kerwer, D., Knill, C., Lehmkuhl, D., Teutsch, M. \& Douillet, A-C. (2001) Differential Europe: The European Union Impact on National Policymaking, Rowman and Littlefield, Lanham, MD.

Heritier, A. \& Knill, C. (2001) 'Differential responses to European policies: a comparison', in Differential Europe: The European Union Impact on National Policymaking, eds D. Kerwer, C. Knill, D. Lehmkuhl, M. Teutsch \& A.-C. Douillet, Rowman and Littlefield, Lanham, MD, pp. 257-294.

Hix, S. \& Goetz, K. H. (2000) 'Introduction: European integration and national political systems', West European Politics, vol. 23, no. 4, pp. 1-26.

Jørgensen, K. E. (1997) 'PoCo: the diplomatic republic of Europe', in Reflective Approaches to European Governance, ed. K. E. Jørgensen, Macmillan, Basingstoke, pp. 167-180.

Jung, D. with Piccoli, W. (2001) Turkey at the Crossroads: Ottoman Legacies and a Greater Middle East, Zed Books, London.

Kassim, H. (2003) 'The European administration: between Europeanization and domestication', in Governing Europe, eds J. Hayward \& A. Menon, Oxford University Press, Oxford, pp. 139-161.

Knill, C. (2001) The Europeanization of National Administrations. Patterns of Institutional Change and Persistence, Cambridge University Press, Cambridge.

Knill, C. \& Lehmkuhl, D. (1999) 'How Europe matters: different mechanisms of Europeanization', European Integration online Papers, vol. 3, no. 7, http://eiop.or.at/eiop/texte/1999-007a.htm.

Kohler-Koch, B. (1999) 'The evolution and transformation of European governance', in The Transformation of Governance in the European Union, eds B. Kohler-Koch \& R. Eising, Routledge, London, pp. 14-35.

Kubicek, P. (2001) 'The earthquake, Europe, and prospects for political change in Turkey', Middle East Review of International Affairs, vol. 5, no. 2, pp. 34-47.

Kubicek, P. (2002) 'The earthquake, civil society and political change in Turkey: assessment and comparison with Eastern Europe', Political Studies, vol. 50, no. 4, pp. 761-778.

Mair, P. (2000) 'The limited impact of Europe on national party systems', West European Politics, vol. 23 , no. 4 , pp. $27-51$.

Manners, I. (2002) 'Normative power Europe: a contradiction in terms?', Journal of Common Market Studies, vol. 40, no. 2, pp. 235-258. 


\section{T. Diez et al.}

Marks, G. (1996) 'An actor-centred approach to multi-level governance', Regional and Federal Studies, vol. 6, no. 2, pp. 20-40.

Morth, U. (2003) 'Europeanization as interpretation, translation, and editing of public policies', in The Politics of Europeanization, eds K. Featherstone \& C. M. Radaelli, Oxford University Press, Oxford.

Olsen, J. P. (2002) 'The many faces of Europeanization', Journal of Common Market Studies, vol. 40, no. 4, pp. 921-952.

Öniş, Z. (2002) 'Domestic Politics, International Norms and Challenges to the State: Turkey-EU Relations in the Post-Helsinki Era', Paper presented at the Annual Meeting of the Middle East Studies Association, Washington DC, Nov. 23-26.

Piccoli, W. (2003) 'European Integration in Turkish Identity Narratives: The Primacy of Security', Paper presented at the 28th Annual British International Studies Association (BISA) Conference, Birmingham, 15-17 Dec.

Radaelli, C. M. (2000) 'Whither Europeanization? Concept stretching and substantive change', European Integration Online Papers, vol. 4, no. 8, http://eiop.or.at/eiop/texte/2000-008a.htm.

Raunio, T. \& Hix, S. (2000) 'Backbenchers learn to fight back: European integration and parliamentary government', West European Politics, vol. 23, no. 4, pp. 142-168.

Risse, T. (2001) 'A European identity? Europeanization and the evolution of nation-state identities', in Transforming Europe: Europeanization and Domestic Change, eds M. G. Cowles, J. A. Caporaso \& T. Risse, Cornell University Press, Ithaca, NY, pp. 203-213.

Risse, T., Cowles, M. G. \& Caporaso, J. (2001) 'Europeanization and domestic change: introduction', in Transforming Europe: Europeanization and Domestic Change, eds M. G. Cowles, J. A. Caporaso \& T. Risse, Cornell University Press, Ithaca, NY, pp. 1-20.

Rumelili, B. (2003) 'Liminality and perpetuation of conflicts: Turkish-Greek relations in the context of community-building by the EU', European Journal of International Relations, vol. 9, no. 2, pp. 213-248.

Rumelili, B. (2004a) 'The European Union's impact on the Greek-Turkish conflict', Working Paper Series in EU Border Conflict Studies, no. 6, Department of Political Science and International Studies, University of Birmingham, http://www.euborderconf.bham.ac.uk/publications/files/ WP6GreeceTurkey.pdf.

Rumelili, B. (2004b) 'The talkers and the silent ones: the EU and change in Greek-Turkish relations', Working Paper Series in EU Border Conflict Studies, no. 10, Department of Political Science and International Studies, University of Birmingham, http://www.euborderconf.bham.ac.uk/ publications/files/GreeceTurkey2.pdf.

Rumford, C. (2001) 'Human rights and democratization in Turkey in the context of EU candidature', Journal of European Area Studies, vol. 9, no. 1, pp. 93-105.

Rumford, C. (2002a) The European Union: A Political Sociology, Blackwell, London.

Rumford, C. (2002b) 'Placing democratization within the global frame: sociological approaches to universalism and democratic contestation in contemporary Turkey', Sociological Review, vol. 50 , no. 2 , pp. $258-277$.

Schimmelfennig, F. (2000) 'International socialization in the New Europe: rational action in an institutional environment', European Journal of International Relations, vol. 6, no. 1, pp. $109-139$.

Schimmelfennig, F., Engert, S. \& Knobel, H. (2003) 'Costs, commitment and compliance: the impact of EU democratic conditionality on Latvia, Slovakia and Turkey', Journal of Common Market Studies, vol. 41, no. 3, pp. 495-518.

Schmidt, V. A. (2001) 'Europeanization and the mechanics of economic policy adjustment', European Integration online Papers, vol. 5, no. 6, http://eiop.or.at/eiop/texte/2001-006a.htm.

Smith, M. E. (2000) 'Conforming to Europe: the domestic impact of European foreign policy cooperation', Journal of European Public Policy, vol. 7, no. 4, pp. 613-631. 
Sofos, A. S. (2001) 'Reluctant Europeans? European integration and the transformation of Turkish politics', in Europeanization and the Southern Periphery, eds K. Featherstone \& G. Kazamias, London, Frank Cass, pp. 243-260.

Tsakonas, P. J. (2001) 'Turkey's post-Helsinki turbulence: implications for Greece and the Cyprus issue', Turkish Studies, vol. 2, no. 2, pp. 1-40.

Uğur, M. (1999) The European Union and Turkey: An Anchor/Credibility Dilemma, Ashgate, Aldershot.

Uğur, M. (2001) 'Europeanization and convergence via incomplete contracts? The case of Turkey', in Europeanization and the Southern Peripher, eds K. Featherstone \& G. Kazamias, London, Frank Cass, pp. 217-243.

Wæver, O. (1998) 'Explaining Europe by decoding discourses', in Explaining European Integration, ed. A. Wivel, Copenhagen Political Studies Press, Copenhagen, pp. 100-146.

Wæver, O. (2004) 'Discursive approaches', in European Integration Theory, eds A. Wiener \& T. Diez, Oxford University Press, Oxford, pp. 197-215. 